\title{
UMA NECESSÁRIA REVISITA A AÇÃO DE CUMPRIMENTO
}

\author{
Jólia Lucena da Rocha Melo ${ }^{1}$ \\ Círlia Natasha Lucena da Rocha ${ }^{2}$
}

Recebido em: 16/12/2017

Aprovado em: 13/02/2018

\begin{abstract}
RESUMO
O texto objetiva a abordagem do instituto da ação de cumprimento, nomenclatura cingida pela literatura jurídica para o instituto criado a partir do artigo 872 da Consolidação das Leis Trabalhistas. Questões intrigantes, a iniciar pela própria atecnia da nomenclatura, a perpassar pela situação da natureza jurídica que envolve referida ação e pela identificação da opção do legislador em como tratá-la, culminando com especificidades a si atinentes (acerca da legitimidade e interesses, procedimento aplicável, objeto e produção probatória, colação de documentos essenciais, marco inicial de prescrição, coisa julgada e honorários advocatícios), merecem a dedicação da sua releitura, na perspectiva de direito coletivo tão festejada (e com razão) nos dias atuais.
\end{abstract}

Palavras-chave: Ação. Cumprimento. Noções. Natureza. Especificidades.

\section{INTRODUÇÃO}

A ação de cumprimento, originariamente criada como instrumento apto a tutelar a concretização das determinações constantes das decisões normativas, conforme incita o artigo 872 da CLT, passou por adaptações necessárias às modificações observadas no contexto normativo e jurisprudencial.

Com o açambarcamento da tutela das determinações tecidas em convenções coletivas de trabalho (CCT) e acordos coletivos de trabalho (ACT), somado à própria verificação da natureza jurídica da ação de cumprimento, questões pontuais também foram ganhando forma.

\footnotetext{
${ }^{1}$ Mestre em Direito do Trabalho e Seguridade Social pela Universidade de São Paulo (USP). Mestranda em Direito pela Universidade Federal do Rio Grande do Norte (UFRN). Especialista em Direito Processual Civil. Juíza do Trabalho.

${ }^{2}$ Mestranda em Direito pela Universidade Federal do Rio Grande do Norte (UFRN). Especialista em Direito e Processo do Trabalho pela Universidade do Estado do Rio Grande do Norte (UERN) e pela Escola da Magistratura do Trabalho da $21^{\text {a }}$ Região (ESMAT 21). Advogada.
} 
Hodiernamente, o tratamento confiado às ações de cumprimento não se pode cingir tão só às problemáticas já pacificadas pela literatura jurídica e jurisprudência, a exemplo da substituição processual (em que pese tenha raízes históricas sob a égide desta ação), do manejo para outros instrumentos normativos que não às decisões normativas, bem como a competência material e funcional para processar e julgar tais demandas.

Nisto, propõe-se um tratamento diferenciado às ações de cumprimento. Assim, ganha espaço a análise da própria natureza jurídica da dita ação sob uma visão mais distanciada da tida outrora. Busca-se, então, o entendimento de questões, nesta seara, a exemplo de ter se tratado ou não de opção do legislador a criação de uma ação diferençada - ação de cumprimento - e não a utilização de uma ação de execução e, ainda, de ter se tratado ou não de opção a criação desta ação diferençada e não a utilização da ação cognitiva trabalhista comum.

De outro lado, desembocando a necessidade premente da tutela jurisdicional adequada no procedimento adequado, resta a análise, neste viés, do próprio procedimento que deveria ser adotado, da questão dos honorários advocatícios sucumbenciais, e, da específica legitimidade adequada às ações de cumprimento.

Ainda no contexto distinto que os envolve, a ação de cumprimento é examinada como propiciadora de visualização diferenciada no tocante aos institutos da prescrição e da coisa julgada.

Por fim, questões intricadas também em relação a outras ações trabalhistas, mas que ganha relevo no tocante a esta modalidade, a juntada de documentos essenciais e a análise do objeto probante e do ônus da prova, também restam como de distinta análise no tocante ao tratamento conferido às ações de cumprimento.

É neste contexto de novas perspectivas que se insere, a necessidade de uma revisita à ação de cumprimento, a qual resta ensaiada neste artigo.

\section{AÇÃO DE CUMPRIMENTO: NOÇÕES GERAIS}

Fato que dispensa comprovações, por negativo, é a ausência de previsão legal para a expressão ação de cumprimento. Não há qualquer rubrica sobre esta modalidade de ação trabalhista na CLT, tendo sido da literatura jurídica a opção por definir como ação de cumprimento toda aquela que instrumentaliza pretensões condenatórias fundadas em 
descumprimento de decisão normativa, em consonância ao disposto no único dispositivo legal a tratar fundamentalmente da matéria (artigo 872 da CLT e seu parágrafo único).

Posteriormente, com o advento da Lei ${ }^{\circ}$ 8.984/95, alargou-se seu objeto, para também designar, formal e legitimamente, aquela que instrumentaliza as pretensões condenatórias consubstanciadas em descumprimento das demais normas provenientes da negociação coletiva, sejam elas veiculadas pelas CCT e ACT.

Quanto à opção da literatura jurídica sobre a nomenclatura da ação examinada, anotou Raimundo Simão que "assim a doutrina a apelidou, pois toda a norma jurídica desrespeitada dá ensejo, a critério do titular do direito violado, a uma ação para cumprimento da norma, seja uma lei no sentido estrito, uma convenção coletiva ou uma sentença normativa."3

Não se discorda das suas ponderações no tocante a ter sido a expressão ação de cumprimento fruto da literatura jurídica, fato este expressado de início. Entretanto, forçoso seria comungar da justificativa de fundamentar a propositura da ação de cumprimento no descumprimento de toda e qualquer norma jurídica, eis que não se encontra como objeto desta ação específica os descumprimentos de leis em sentido estrito, como se fez parecer pela leitura antes realizada.

A ação de cumprimento apenas encontrará guarida quando o descumprimento se der em relação a normas trabalhistas autonomamente constituídas e normas criadas anomalamente em decorrência do Poder Normativo da Justiça do Trabalho. É, inclusive, este o motivo da sua existência particularizada no ordenamento jurídico pátrio.

Ainda no que atine à nomenclatura, sob outro aspecto, visível a atecnia do legislador trabalhista ao mencionar cumprimento, e, da literatura ao optar por nomear dito instituto de ação de cumprimento, eis que o termo cumprimento expressa noção executiva, a qual não coteja o propósito primário do instituto: propiciar a aplicação, em espécie, do ordenamento jurídico anunciado na decisão normativa e nos negociados coletivos, ACT e CCT.

Persistindo na infelicidade técnica do legislador trabalhista, insta anotar que a lei processual civil, atualmente, se utiliza da expressão cumprimento de sentença, a qual, também, não coaduna com o significado do objeto deste estudo, mas sim da possibilidade que tem o sucumbente de cumprir a determinação sentencial inobstante inexista execução forçada.

Assim, o emprego da expressão ação de cumprimento, neste estudo, se rende mais ao fato de ter sido assim popularizada pela literatura jurídica que à sua especificidade técnica.

\footnotetext{
${ }^{3}$ MELO, Raimundo Simão de. Ação civil pública na justiça do trabalho. $3^{\text {a }}$ edição. São Paulo: LTr, 2008, p. 228.
} 
Afora as críticas atinentes a expressão, não se pode descuidar em considerar que a compreensão do surgimento da ação de cumprimento se encontra imbricada a uma questão fático-metodológica da formação anômala da norma jurídica pelo poder normativo da Justiça do Trabalho, tendo em vista que aquele instrumento de acesso à justiça, inicialmente, teve por escopo a concretização, ou individualização, de direitos criados através do poder normativo.

Foi do ponto de vista da formação da norma jurídica trabalhista pelo Poder Judiciário que se suscitaram, e ainda se suscitam, os mais diversos questionamentos que seguem pela divisão de poderes constitucionais ${ }^{4}$, natureza da decisão normativa ${ }^{5}$, e, inclusive, que guarda reflexos óbvios no campo processual trabalhista, mais insitamente no que se refere ao mecanismo a ser utilizado para concretização da norma abstrata criada pelo Poder Judiciário e não pelo Poder Legislativo, como seria o ordinário. Tratando-se de uma situação observada como extraordinária, até pela sua tão considerável atipicidade se dar apenas no Brasil, Austrália, Nova Zelândia e México ${ }^{6}$, nada mais previsível que tendesse o legislador pela criação de um mecanismo apropriado à tutela dos direitos e/ou interesses dela provenientes.

A ação de cumprimento, pois, representou, inicialmente, a necessária criação de um instituto jurídico adequado a garantir a ordem jurídica criada anomalamente pelo Poder Judiciário a partir do dissídio coletivo, dada a própria natureza dúplice que se procura conferir à norma criada. Em outras palavras, a esfera processual do direito acompanhou a pluralidade de criadores de normas jurídicas trabalhistas ao trazer o instrumento da ação de cumprimento.

Com o sucesso das ações de cumprimento nas decisões normativas, o âmbito do objeto se alargou a fim de se verificar também sua individuação nas CCT e ACT, com o aceite da pluralidade normativa.

Destarte, conceituável a ação de cumprimento como toda aquela que visa a instrumentalizar pretensões condenatórias fundadas no descumprimento das normas autonomamente criadas pelos atores sociais e das decisões normativas.

\footnotetext{
${ }^{4}$ A função legiferante é competência genuína do Poder Legislativo. Contudo, conforme se apreende nas lições do Direito Constitucional, a tripartição dos poderes existe de forma relativizada, de modo a assegurar a própria manutenção do sistema. Assim, como o Poder Legislativo e o Executivo exercem funções atípicas, o Poder Judiciário, de forma atípica, também vem a exercer funções de caráter administrativo e legislativo, sendo exemplo deste último o Poder Normativo atribuído à Justiça do Trabalho.

5 Em lição acerca de convenções coletiva, tomadas por empréstimo às decisões normativas, pela mesma discussão quanto à natureza jurídica, não se pode deixar de anotar que "manifestam uma relação peculiar entre os domínios do contrato e da norma jurídica [...] e este facto suscitou, desde o surgimento destes instrumentos e até hoje, grandes dificuldades à sua compreensão nos quadros dogmáticos do direito comum e um amplo debate sobra a questão da sua natureza jurídica”. (RAMALHO, Maria do Rosário Palma. Da autonomia dogmática do direito do trabalho. Coimbra: editora Almedina, 2000, p. 800-801).

${ }^{6}$ MARTINS FILHO, Ives Gandra. Processo coletivo do trabalho, 2a ed., São Paulo: LTr, 1996, p. 33-35.
} 
2.1 Da natureza jurídica da ação de cumprimento.

Tecer ponderações acerca da natureza jurídica de um determinado instituto é buscar, em seus elementos, a sua qualificação no seio do ordenamento. Com a ação de cumprimento não se poderia diferençar.

Definir a natureza jurídica das ações pela classificação quinária como declaratórias, constitutivas, condenatórias, mandamentais ou executivas, contudo, na visão de grande parcela dos processualistas, v.g. Teixeira Filho, comporia impropriedade científica, eis que a ação “não pode ser adjetivada de 'declaratória', 'constitutiva' e o mais. Assim dizemos porque a ação constitui um direito subjetivo público, de natureza constitucional, de invocar-se a prestação da tutela jurisdicional do Estado".

Entretanto, por não se poder olvidar a difusão do uso pela literatura jurídica dos adjetivos próprios às tutelas como se o fossem às ações em si, utiliza-se a referida categorização para explicitar a tutela pretendida com a ação de cumprimento.

À época da construção do instituto sub examinem, não se ouviam menções às tutelas mandamentais e executivas lato senso, sendo, portanto, aplicável a classificação tríade. Tal fato pode sugerir que para tanto não haveria como se categorizar a tutela da ação de cumprimento como sendo de índole executiva lato senso.

Contudo, a falsa premissa não merece prosperar. Não foi a simples inexistência de categorização de tutelas executivas lato senso o óbice à classificação da tutela almejada com ação de cumprimento a dito grupo, mas o não enquadramento de referida tutela a este rótulo.

A ação de cumprimento fundava-se, inicialmente, na decisão normativa, a que posteriormente se juntaram o acordo coletivo e a convenção coletiva de trabalho. Não se pode abstrair a proeminência do aspecto normativo de tais instrumentos, muito embora estudos sobre a temática indiquem uma vasta discussão acerca da natureza jurídica, enquanto o aspecto normativo ou aspecto contratual ${ }^{8}$.

\footnotetext{
${ }^{7}$ P. 09. Interessante ainda trecho onde Teixeira Filho conclui: "quando se classificam as ações em declaratórias, constitutivas, condenatórias, etc., se está levando em conta não a ação, propriamente dita em seu sentido ontoteleológico, mas a sentença que se visa a obter. As sentenças, estas sim, se submetem a tais classificações (tríade ou quinaria, conforme se queira)". (TEIXEIRA FILHO, Manoel Antônio. Curso de processo do trabalho: perguntas e respostas sobre assuntos polêmicos em opúsculos específicos, n. 27: ação de cumprimento. São Paulo: LTr, 1998, p. 09)

8 "Todos esses instrumentos têm a mesma natureza normativa, são dotados de igual conteúdo (fixam condições de trabalho) e dizem respeito às mesmas partes que formam os pólos ativo e passivo da ação de cumprimento. $O$ inadimplemento que fundamenta a ação não é peculiar à sentença normativa, mas comum a
} 
As normas coletivas, dentre as quais se pode incluir, pela atuação mais direta dos atores sociais, o dissídio coletivo, constituem, juntamente às normas heterônomas propriamente ditas, o arcabouço normativo juslaboral.

A ação executiva se delimita no provimento jurisdicional que se faz atuar o direito a partir dele. A sentença da ação de cumprimento, por óbvio, imprescinde da fase executiva forçada do processo, caso o pólo passivo atingido pelo seu provimento não satisfaça a obrigação espontaneamente após a prolação da decisão.

De fato, a tutela apresentada pela sentença da ação de cumprimento é a condenatória, conferindo ao autor, caso procedente a postulação, título executivo para o transpasse à fase executiva do processo.

Perpassada esta apresentação, vislumbram-se as causas mais afetas às problemáticas que envolvem a ação de cumprimento.

2.2 Opções do legislador: ação de cumprimento ou de ação de execução? Ação trabalhista ou ação de cumprimento?

Como já anotado, a ação de cumprimento tem seu berço histórico na necessidade de fazer cumprir as decisões normativas, sendo estas consubstanciadas em produtos de competência dos Tribunais do Trabalho. Assim, questiona-se: por possuir dita competência, não teria este mesmo órgão competência para executar o seu julgado?

O questionamento não merece uma resposta afirmativa. A decisão normativa, embora constituída a partir de jurisdição, com o processo, e todos os seus requisitos e condições, cria regras gerais a serem aplicadas em relação a uma dada coletividade representada.

Assim, em tendo a decisão normativa o caráter essencialmente de norma, em que pesem as opiniões adversas ${ }^{9}$, é notório o seu grau de abstração e impessoalidade, o mesmo decorrendo em relação às convenções e aos acordos coletivos de trabalho.

Tratam-se, os três, - decisões normativas, CCT e ACT - de instrumentos coletivos exteriorizados com o fito de regular relações de trabalho in abstracto, de forma geral, tal qual o que ocorre com uma lei stricto senso, em que pese aqueles, em regra, apresentarem um grau de generalidade um pouco mais restrito quanto ao âmbito da coletividade a que se destina.

qualquer desses instrumentos". (SÜSSEKIND, Arnaldo; MARANHÃO, Délio; VIANNA, Segadas; TEIXEIRA FILHO, João de Lima. Instituições de direito do trabalho, vol. 2. 19ạ ed. São Paulo: LTr, 2000. p. 1418).

${ }^{9}$ Cf. SANTOS, Ronaldo Lima dos. Teoria das normas coletivas. $2^{\text {a }}$ edição. São Paulo: LTr, 2009. 
Assemelham-se à lei em sentido estrito e às normas coletivas de trabalho, por tanto uma quanto outra preconizarem a criação de direitos e novas condições de trabalho, procedendo na constituição e declaração normativa, elementos que as levam a ser consideradas fontes do direito do trabalho.

Daí se apresenta um novo questionamento: qual o motivo de se prever um instrumento acionário específico em vias cognitivas e não um instrumento acionário específico a tais tutelas, já em via executória?

A resposta encontra assento na própria natureza jurídica das normas coletivas autônomas e das decisões normativas. Enquanto criadas por pessoas distintas, as primeiras pelos atores sociais e as últimas pelo Poder Judiciário a partir da iniciativa dos atores sociais, guardam a similaridade de não serem criadas pelo Poder originariamente criativo de normas jurídicas, o Poder Legislativo. Contudo, guardam outra similaridade de comporem, junto a tal criação normativa do legislativo, um plexo de normas.

Nesta última similitude se explicita a resposta antes afirmada. O sistema prevê a ação de cumprimento enquanto ação cognitiva, e não já executiva, ante a ausência de título executivo formado. Tem-se uma abstração genérica, a qual imprescinde da afirmação do Juízo para, aí sim, formar-se um título executivo, e dar ensejo a fase executiva do processo. ${ }^{10}$

Não poderia o sistema comportar-se de modo inadequado causando choque à sua própria estrutura processual. $\mathrm{O}$ arbítrio se formaria na esfera processual, eis que sem título executivo, e sem previsão de sua existência (onde se poderiam enquadrar as hipóteses de tutela de urgência), se passaria ao cumprimento de uma obrigação que sequer se saberia existir.

No mais, pensar de outro modo - em que pese o argumento de que sem o título executivo impossibilitar-se-ia por si só a tutela executiva - seria o mesmo que forçar a uma impensável hierarquia das normas criadas pelo Poder Judiciário anomalamente às normas criadas pelo Poder Legislativo.

Argumentos no sentido de que as normas coletivas deveriam ter o mesmo escopo dos acordos individuais, dos laudos arbitrais ou termos de ajustamento de conduta provenientes do Ministério Público do Trabalho (MPT), firmados em títulos executivos, não encontram respaldo.

Prever uma ação de cumprimento, de caráter cognitivo, não se faz por mero critério

\footnotetext{
10 “A ação de cumprimento é, pois, de natureza condenatória, por visar a um pronunciamento jurisdicional que imponha ao rei acatamento a cláusulas constantes de acórdão normativo, podendo, essa condenação, implicar obrigação de pagar quantia certa, de fazer ou não fazer e o mais. Conseguintemente, a sentença emitida na causa converter-se-á em título executivo judicial [...]”. (TEIXEIRA FILHO, Manoel Antônio. Op. cit., p. 12).
} 
discriminador negativo destes outros instrumentos firmados, como se poderia imaginar.

Ocorre que, como já anotado, as decisões normativas e as normas coletivas têm naturezas diversas dos acordos individuais homologados, dos laudos arbitrais e termos de ajustamento de conduta. E, enquanto àquelas tratam abstratamente das hipóteses, estes instrumentos traçam a solução do litígio de modo individualizado, a partir de uma posta situação, não sendo válida, assim, a comparação em idênticos termos por se tratarem de instrumentos totalmente diferenciados.

Satisfeitos os principais pontos da discussão sobre uma primeira opção do legislador, outro questionamento se reflete: por que se criou uma novel ação diferençada e não simplesmente se adotou a ação trabalhista comum?

Não se pode desconsiderar nesta reflexão, novamente, os aspectos da origem desta ação. Seu veículo normativo (art. 872 da CLT) teve por escopo primeiro instrumentalizar pretensões oriundas das decisões normativas, eis que, além da crível celeuma sobre a competência, tinha a função de indicar o instrumento no qual se perfaria o acesso à justiça em tais casos.

Dito de outra forma, a distinção que se guarda entre uma norma criada pelo poder normativo (de certo modo a partir da autonomia coletiva, eis que indispensável a manifestação do ente coletivo para sua operação) e as normas originariamente oriundas do Poder Legislativo, desemboca, dentre outros aspectos, na necessidade de criação de um mecanismo diferenciado da comum ação trabalhista, a fim de tratar de aspectos mais específicos a exemplo da limitação de fase probatória (vez que já houve pronunciamento judicial), da necessidade de colacionar certidão da decisão, pela substituição processual (sendo a ação de cumprimento precursora na utilização deste instituto, não utilizado, à época, nas ações comuns) etc..

A ação de cumprimento, embora se regendo no mesmo procedimento conferido às ações trabalhistas em geral, guardava, em seus aspectos legais, peculiaridades que faziam exigir a existência de um mecanismo diferenciado.

Hodiernamente, sua diferenciação ainda se justifica pela existência não só de alguns elementos legais remanescentes - v.g, no caso das decisões normativas, da limitação da fase probatória, mas também por elementos acrescentados pela doutrina e jurisprudência, a exemplo das peculiaridades da prescrição, haja vista a temporalidade das convenções e acordos coletivos, e, da coisa julgada rebus sic stantibus.

É verdade, entretanto, que por se submeter ao mesmo procedimento ao qual se submetem as demais ações trabalhistas, e, dada a corriqueira cumulação de pedidos ínsita ao 
processo do trabalho, é comum que em uma determinada ação trabalhista se encontrem pedidos afetos tanto às leis stricto senso quanto às normas coletivas, não sendo incomum ainda a utilização genérica da nomenclatura ação trabalhista para toda e qualquer ação, pouco importando as peculiaridades que as distinguem.

Contudo, as peculiaridades existem e merecem reexame, motivo pelo qual se segue a análise da fase probatória da ação de cumprimento, da questão da juntada de documentação indispensável, da coisa julgada, da prescrição e dos honorários advocatícios.

\section{AS ESPECIFICIDADES DAS AÇÕES DE CUMPRIMENTO}

\subsection{Legitimidade e interesses}

Impera anotar que a dicção legal do art. 872 da CLT faz revelar que a sentença normativa, ao que se somaram posteriormente as convenções e acordos coletivos, podem ser cumpridas de forma individual, pelo próprio trabalhador ou grupo de trabalhadores (com via litisconsorcial) ou a título coletivo, com a substituição processual (via sindicato), nos casos de direitos individuais homogêneos.

Desse modo, a ação de cumprimento pode adquirir feição individual ou coletiva, havendo, portanto, legitimidade concorrente para a propositura da supramencionada ação entre o sindicato e os empregados.

Os sindicatos são considerados substitutos processuais, vez que atuam em nome próprio na defesa de interesses alheios, sendo estes individuais homogêneos. Não é de outra forma que, nesta hipótese, a ação de cumprimento se consubstancia como verdadeira ação coletiva, nos mesmos moldes que se cingem no CDC, em seu art. 92. ${ }^{11}$

Embora o art. 872 da CLT não mencione a legitimidade das federações, confederações e grupo de trabalhadores, tem-se pela lógica do sistema coletivo, que na ausência ou inorganização de sindicatos representativos, a legitimidade resta assegurada às federações, na falta também destas às confederações e, por fim, na inexistência destas, a grupos de trabalhadores formados para tanto, uma vez que neste contexto se encontra garantido o acesso à justiça pela classe.

\footnotetext{
11 Fato que deve ser considerado é que o art. 872 da CLT foi inovador ou tratar, na égide da ação de cumprimento, a situação de substituição processual de forma revolucionária à época, consistindo-se, portanto, em vanguardista neste sentido. (SILVA, Homero Batista Mateus. Curso de direito do trabalho aplicado, vol. 7: - direito coletivo do trabalho. Rio de Janeiro: Elsevier, 2010, p. 215).
} 
Considerando a substância de ação coletiva que adquire a ação de cumprimento quando é o sindicato que age, enquanto substituto processual, curioso questionamento se assume acerca da legitimidade do MPT para atuar na defesa dos direitos individuais homogêneos previstos nas normas coletivas e sentenças normativas.

Situação que suscita maior grau de dúvida é a concernente à legitimidade ou não do MPT e das empresas ou sindicatos patronais para atuarem como legitimados ativos nas ações de cumprimento.

Quanto ao primeiro mote, há de se recordar ser o MPT ente legitimo a atuar na tutela coletiva dos direitos difusos, coletivos e individuais homogêneos. A Lei n 75/93 não dispõe de modo diverso, e bem recentemente o TST, seguindo a esteira do STF, deu mais uma mostra da legitimidade do MPT na atuação protetiva de direitos individuais homogêneos.

Não se vê razão para negar tal legitimidade ao MPT, quando no tocante à legislação heterônoma não se encontra grande resistência à tutela, por este órgão, dos direitos individuais homogêneos.

Quanto à legitimidade ativa das empresas e dos sindicatos patronais, registra-se não haver específica previsão legal. Contudo, dado que o acesso à justiça, ante a própria noção conferida pelo contraditório, deve ser fornecido a ambos os atores (o que se consubstancia no fato das normas coletivas e sentenças normativas encerrarem obrigações duais), não se vê motivos, conforme o ordenamento jurídico, para essa negação díspar.

\subsection{O procedimento aplicável}

Tornando a considerar a substância de ação coletiva na qual se reveste a ação de cumprimento quando é o sindicato que age, enquanto substituto processual, não é demais constar que o tratamento legal se segue a partir do aparato normativo coletivo (CF, CDC, LACP) e não diretamente pelo individual, diverso do compreendido quando o trabalhador, individualmente, ou alguns trabalhadores, em litisconsórcio, ingressam com a dita ação.

Contudo, tendo-se por esteio a ausência de previsão legal de um procedimento específico às demandas de natureza coletiva e a dicção expressa do art. $1^{\circ}$ da Instrução Normativa $\mathrm{n}^{\circ} 27 / 2005$ do TST, o procedimento a ser seguido, quer se trate de tutela coletiva ou individual, é o mesmo adotado para as ações individuais (procedimentos ordinários, sumaríssimos e sumários, a depender do valor da causa), o que implica em amoldar um litígio de direitos coletivos na sistemática dos procedimentos adotados pela CLT originariamente criados para as situações classicamente individuais. 
A crítica, no caso, se presta ante o próprio caráter instrumental do processo, hoje, sobretudo, tão festejado. O processo deve se amoldar, dentro do possível, ao direito material, haja vista ser para o plano da substancialidade que se centra sua finalização, jamais se devendo apresentar o inverso, sob pena de constituir-se no indesejado fim em si mesmo. ${ }^{12}$

A ausência de tratamento procedimental adequado às tutelas coletivas é mais um dos aspectos que se apresenta como óbice a tão necessária coletivização.

\section{$3.3 \mathrm{O}$ objeto e a produção probatória nas ações de cumprimento}

O artigo 872 da CLT traz em seu texto a vedação de se questionar, durante o procedimento a que se submete a ação de cumprimento, matéria de fato e de direito já apreciada na decisão normativa, limitando o objeto da lide.

Tendo sido originariamente a ação de cumprimento criada apenas para instrumentalizar as pretensões fundadas em decisões normativas, tem-se por compreensível a dita determinação, eis que apesar de considerável o seu caráter normativo, não se descarta o fato de ter-se originado da atuação jurisdicional.

Destarte, já havendo um posicionamento jurisdicional com a decisão normativa, ter-seia em contrassenso o reexame da matéria fática e de direito por um juiz de $1^{\circ}$ grau sobre o que já restou verificado pelo órgão competente para o julgamento do dissídio coletivo.

Neste sentido, em relação às decisões normativas, “o que a lei proíbe, na verdade, é a discussão sobre matéria factual e jurídica em que se baseou o acórdão normativo, objeto da ação de cumprimento."13

Já quanto às convenções e acordos coletivos de trabalho, obviamente, não se perfaz aplicável a dicção do art. 872 da CLT no âmbito da análise probatória e do objeto, eis que não se precedeu a qualquer exame de fatos e/ou direito com pronunciamento judicial anterior.

Fazendo uma digressão, sem desmerecer o disposto no inciso XXVI do art. $7^{\circ}$ da $\mathrm{CF}$ sobre o reconhecimento das convenções e acordos coletivos de trabalho, é, inclusive, de se esperar que o controle acerca do direito esmiuçado nestes instrumentos, na atual conjuntura apresentada, tenha um maior grau que o controle exercido acerca das leis trabalhistas editadas pelo Poder Legislativo e acerca das decisões normativas.

\footnotetext{
12 “A natureza instrumental do direito processual impõe sejam seus institutos concebidos em conformidade com as necessidades do direito substancial. Isto é, a eficácia do sistema processual será medida em função de sua utilidade para o ordenamento jurídico material e para a pacificação social". (Bedaque, Direito e processo: influência do direito material sobre o processo. $5^{\text {a }}$ ed. São Paulo: Malheiros, 2009, p. 19).

${ }^{13}$ TEIXEIRA FILHO, Manoel Antônio. Op. cit., p. 35.
} 
Embora ambas possam vir a lesar o ordenamento jurídico, tanto no tocante ao descompasso com a Constituição quanto ao descompasso com normas mais favoráveis, o pensamento corriqueiro é que: quanto aos acórdãos coletivos, mesmo se perfazendo em normas, são oriundos de processos autônomos, o que faz lembrar a "participação direta de todos os envolvidos, além de acesso a ampla recorribilidade" ${ }^{״ 1}$, e, presença do Estado juiz; e, quanto às leis estrito senso, o Poder Legislativo já se encontra mais afeto a produções legislativas, com a escorreita verificação das diretrizes jurídicas, que os sindicatos. ${ }^{15}$

Teoricamente, sob a égide do sistema sindical propugnado pela OIT, conforme disposto na convenção $\mathrm{n}^{\circ} 163^{16}$, era de se esperar exatamente o inverso - um menor grau de desconfiança da legislação autônoma - uma vez que as normas coletivas trazem em seu seio a demonstração mais efetiva dos desejos da coletividade açambarcada, o que se presume pelo próprio caráter de democracia mais evidenciado.

Contudo, tal teoria não coaduna com a prática do sistema sindical brasileiro, o qual, pelo princípio da unicidade sindical e através das contribuições compulsórias, se reflete em profunda ausência de representatividade e, assim, do caráter democrático, não sendo incomum que as flexibilizações trabalhistas tendam a ser encartas no centro de tais normas, o que faz exigir, uma atuação mais enfática no tocante ao exame do direito.

Em outras palavras, tomando o nosso sistema por base, se a legislação heterônoma, gerida pelo Estado, contando com etapas de procedimento legislativo no qual se podem verificar as distorções, ainda as instrumentaliza, o que dizer de normas coletivas muitas vezes manipuladas pelo interesse empresarial, a partir das falhas evidenciadas do sistema?

Assim, quanto às ações de cumprimento fundadas em ACT e CCT, além da análise das provas no contexto fático, afigura-se ainda como extremamente necessária a análise do direito instrumentalizado, eis que imprescindível sopesar sua constância ao ordenamento jurídico.

Guarda o juiz do trabalho, neste tocante, uma atuação sobre o direito ainda mais ativa, eis que direitos trabalhistas podem ser vilipendiados não só com as atitudes do empregador no

\footnotetext{
${ }^{14}$ SILVA, Homero Batista Mateus. Op. cit., p. 232.

${ }^{15}$ Contudo, não se pode deixar de evidenciar que para a situação democrática ansiada, a negociação coletiva atende de maneira mais específica que a lei certas situações. "A negociação tem maior possibilidade de atender as peculiaridades de cada setor econômico e profissional ou cada empresa para qual é instituída. A legislação é geral, uniforme para toda a sociedade. A negociação é específica, para segmentos menores. Permite a autorregulamentação de detalhes que a lei, norma de ordem geral, para toda a sociedade, não pode nem deve reger". (NASCIMENTO, Amauri Mascaro. Compêndio de direito sindical. 2. ed. São Paulo: LTr, 2000, p. 270).

16 "A Recomendação n 163 da OIT declara que o direito de negociação deve ser amplo, assegurando a todas as organizações, em qualquer nível de empresa, estabelecimento, ramo de indústria, região ou até em nível nacional, coordenados esses níveis entre si”. (SANTOS, Enoque Ribeiro dos. A negociação coletiva de trabalho como instrumento de pacificação social. In THOME, Candy Florêncio; SCHWARZ, Rodrigo Garcia (Org.). Direito coletivo do trabalho: curso de revisão e atualização. Rio de Janeiro: Elsevier, 2010, p. 64.).
} 
mundo fático, mas pelas próprias previsões normativas autônomas. Trata-se de uma atuação, neste plano processual, que tem por fim evitar que as desigualdades econômicas, oriundas inclusive do próprio sistema sindical atual (que redunda na ausência de representatividade da coletividade de trabalhadores), se reflitam também no campo processual.

Entretanto, alerta Homero Mateus que, por não ter se submetido tal documento ao crivo do Judiciário, "abre-se uma brecha para a discussão de sua constitucionalidade, mas, simultaneamente, corre-se o risco de argüir a própria torpeza, porque aquele que anuiu com a cláusula dificilmente poderá dizer que ela é abusiva. ${ }^{17}$

Mais especificamente quanto à matéria fática, dúvidas não restam quanto à necessidade de sua comprovação, seja em relação às decisões normativas, desde que não examinadas nestas, seja em relação às convenções e acordos coletivos. Contudo, a mesma atividade do juiz deve persistir, desta feita, através dos poderes probatórios, a fim de propiciar a correção das distorções do campo econômico no processo.

A leitura de Bedaque implica em entendimento, plenamente utilizável também no contexto das normas coletivas quando do manejo da ação de cumprimento:

\begin{abstract}
A real igualdade das partes no processo somente se verifica quando a solução encontrada não resultar da superioridade econômica ou da astúcia de uma delas. $\mathrm{O}$ processo não é um jogo, em que o mais capaz sai vencedor, mas um instrumento de justiça com o qual se pretende encontrar o verdadeiro titular de um direito ${ }^{18}$.
\end{abstract}

Quanto à iniciativa probatória do juiz do trabalho em ações de cumprimento, nota-se que, com ela, as desigualdades econômicas expostas na criação das normas coletivas, e até no plano fático, se esmaecem. É que o manejo do critério de julgamento supletivo observado na distribuição do ônus da prova perde espaço com o uso dos poderes instrutórios. ${ }^{19}$

\title{
3.4 A colação de documentos essenciais
}

No mesmo teor do explicitado anteriormente, questiona-se a importância da juntada do acórdão normativo, convenção ou acordo coletivo, sob os quais se pauta a demanda.

No parágrafo único do art. 872 da CLT, tem-se a afirmação de que deve haver a

\footnotetext{
${ }^{17}$ SILVA, Homero Batista Mateus. Op. cit., p. 233.

${ }^{18}$ BEDAQUE, José Roberto dos Santos. Poderes instrutórios do juiz. $4^{\mathrm{a}}$ ed. São Paulo: Revista dos Tribunais, 2009, p. 101-102.

${ }^{19}$ Entretanto, além da iniciativa probatória do juiz do trabalho, também nas ações de cumprimento, constituirse em efetivo instrumento democratizante, não se pode olvidar, da atividade probatória das próprias partes, eis que aquela não tem o condão de substituir esta também no âmbito das ações de cumprimento.
} 
juntada da certidão da decisão normativa. Embora não explicitada pelo texto legal, a regra açambarca a necessidade de juntada das convenções e acordos coletivos.

\begin{abstract}
Diante do grande número de decisões coletivas, não seria possível aos juízes conhecê-las todas, como têm obrigações de conhecer todas as leis federais. Assim, para propor ação de cumprimento, deve o interessado comprovar o teor da norma coletiva, mediante certidão ou cópia autenticada do acórdão. Como os Tribunais podem retardar a redação e publicação dos acórdãos em processos coletivos, a Lei n. $7.701 / 88$ autorizou o ajuizamento da 'ação de cumprimento a partir do $20^{\circ}$ (vigésimo) dia subseqüente ao do julgamento, fundada no acórdão ou na certidão de julgamento, ${ }^{20}$
\end{abstract}

Não se tratando de norma federal, o juiz não é obrigado a conhecê-la, ao que deve, conforme leitura clássica, ser o direito comprovado por quem o alegou. Nesta linha:

O não-cumprimento da exigência torna a exordial inepta e possibilita ao juízo extinguir o processo sem julgamento de mérito (art. 267, I, CPC), posto que a petição inicial deve ser instruída com os documentos necessários à propositura da ação (art. 283 do CPC). Antes, porém, do indeferimento, caberá ao juízo determinar que a parte cumpra a existência no prazo de 10 (dez) dias, sendo indeferida a petição inicial se não cumprida a determinação. ${ }^{21}$

Homero Mateus, de outro lado, critica o aduzido quanto a novo prazo para juntada, vez que tal regalia não é oferecida à ré e complementa que isto "seguramente viola o tratamento igualitário às partes. A tese sobre a concessão de prazos para o autor juntar mais documentos sem os quais ia perder a pretensão decorre de uma leitura apressada que se faz sobre o art. 284 do Código de Processo Civil." 22 Sendo tal leitura feita agora com respaldo no art. 321 do atual Código de Processo Civil, o qual aumentou o prazo de 10 para 15 dias.

Conste-se, ainda, que a ausência de tal documento ocasiona o não conhecimento acerca da existência do direito ou não, de forma a não ser incomum, em julgados, ao invés da verificação da inépcia, a improcedência de pedidos nele arrimados, o que causa um prejuízo gritante ao jurisdicionado e à jurisdição. O pensamento que se tem, para tal tipo de posicionamento, é que se a parte que incumbia comprovar a existência de norma coletiva prevendo determinado direito não o fez, esse não existia.

De um modo ou de outro, não se pode descurar do aspecto cooperativo e da dinâmica que se assume na produção de provas, o que se pode anotar, também em relação aos documentos normativos.

\footnotetext{
${ }^{20}$ GIGLIO, Wagner D. Direito processual do trabalho, $13^{a}$ ed. São Paulo: Saraiva, 2003, p. 402.

${ }^{21}$ SANTOS, Ronaldo Lima dos. Sindicatos e ações coletivas - acesso à justiça, jurisdição coletiva e tutela dos interesses difusos, coletivos e individuais homogêneos. $2^{a}$ ed. São Paulo: LTr, p. 322.

${ }^{22}$ SILVA, Homero Batista Mateus. Op. cit., p. 230.
} 
É que o juiz, como já dito alhures, assume, atualmente, uma posição mais ativa, o que determina que para possibilitar uma mais correta prestação jurisdicional, lance mão de seus poderes instrutórios, a fim de uma apuração mais completa dos fatos instrumentalizados pela norma coletiva. Nesse caso, para salvaguardar a instrução processual, deve o juiz buscar, primeiramente, a obtenção de conhecimento acerca da norma coletiva, para só a partir desta, propiciar-se a análise dos pedidos.

\begin{abstract}
Não se pode esquecer que a ciência processual evoluiu. Com o tempo, a visão dos problemas processuais tem se modificado. Hoje pensa-se mais em justiça e menos em técnica ou ciência processual. Para que a decisão seja substancial e qualitativamente justa, não basta assegurar às partes exclusividade de iniciativa no processo, ainda que com garantia de ampla participação. É preciso buscar, pelo processo, a aplicação correta e racionalmente justificada do direito. Para atingir esse objetivo, fundamental é a preocupação com a verdade dos fatos. Somente a solução baseada em fatos verdadeiros pode ser considerada justa ${ }^{23}$.
\end{abstract}

Destarte, em que pese os artigos 283 e 267, I, ambos do CPC, indiquem o caminho da extinção do processo sem resolução do mérito caso a parte não colacione aos autos a norma coletiva que embasa os pedidos da ação de cumprimento, nada obsta que o juiz, no poderdever instrutório que lhe incumbe, busque, por outros meios, como a redistribuição da iniciativa de prova neste tocante (se perceptivelmente mais fácil ao pólo passivo colacionar) ou determinação de cumprimento de diligência, aos sindicatos, da juntada da norma coletiva.

Pensa-se de maneira diversa da corrente majoritária. A determinação dos artigos 320 e 485, I, ambos do CPC, não se presta a aplicar sanção à parte que alega fato e não o comprova, tal como certamente ocorre com o instituto da revelia, mas se inscreve como mecanismo processual integrador, o que é útil para, nos casos em que o conhecimento da norma não se faça possível, evitar-se o non liquet, pois obstado ao magistrado se eximir de julgar.

Funciona, assim, dita previsão de extinção anômala do processo, em tal situação, em idêntico sentido do funcionamento das regras de distribuição do ônus da prova previstas no art. 373 e seus incisos, I e II do CPC. Ou seja, funciona como mecanismo supletivo utilizado por ocasião do julgamento quando da não consecução do material probatório que leve o magistrado ao convencimento pretendido.

Quanto mais extintos os processos sem resolução do mérito por ausência de documentação essencial, mais certo se tem que o juiz não está exercendo os poderes a si conferidos, bem como que a atividade jurisdicional não está sendo realizada em completude ${ }^{24}$.

\footnotetext{
${ }^{23}$ BEDAQUE, José Roberto dos Santos. Poderes instrutórios..., cit., p. 107.

${ }^{24}$ Opera-se, nessa medida, de igual forma ao estudo da distribuição do ônus da prova: "Não há dúvida de que a atividade instrutória por parte do juiz pode diminuir os casos em que seja necessário recorrer às normas de distribuição dos riscos pela obscuridade dos fatos. Ou seja, se além das partes também o juiz desenvolve esforços
} 


\subsection{O marco inicial da prescrição}

A existência da prescrição se justifica no fato de que "o Estado não pode permanecer indefinidamente à disposição da parte inerte, de tal forma que a exigibilidade do direito, sua eficácia ou sua coerção têm prazo de validade.",25

No tocante às pretensões veiculadas por ações de cumprimento quanto a descumprimento de cláusulas constantes em convenções e acordos coletivos, o prazo prescricional começa a ser contado a partir da lesão ao direito açambarcado pela norma coletiva, e, por óbvio, após a entrada em vigor desta, guardando total similaridade do que ocorre quando o direito é veiculado pela legislação estrito senso, bem dizer, com total vinculação ao disposto na CF sobre prazos prescricionais (art. $7^{\circ}, \mathrm{XXIX).}$

Aspecto, contudo, que muito diferencia a ação de cumprimento da ação trabalhista regularmente conhecida é o concebido no marco inicial da prescrição em caso de consubstanciada em decisão normativa, visto que, nesta situação, a norma provém da atividade jurisdicional que, como tal, se amolda a institutos como o da coisa julgada.

O problema ganha corpo pela inexigibilidade do trânsito em julgado da decisão normativa para o ingresso da ação de cumprimento, conforme sinaliza Súmula ${ }^{\circ} 246$ do TST.

Com visão pelo ângulo prescricional, apresenta-se o questionamento acerca da contagem de um prazo prescricional em relação a um direito que sequer se encontra definitivamente previsto na ordem jurídica. Em palavras desapegadas da técnica jurídica: como dizer que algo já está morto se ainda não nasceu efetivamente?

O TST traz a sua solução para a problemática na Súmula $n^{\circ} 350$, a qual enuncia “o prazo de prescrição com relação à ação de cumprimento de decisão normativa flui apenas da data de seu trânsito em julgado."

É que embora tenha a parte, a faculdade de ingressar com a ação de cumprimento mesmo antes do trânsito em julgado da decisão normativa, este potencial exercício antecipado

\footnotetext{
para obtenção da prova, maior a possibilidade de esclarecimento dos fatos, o que diminui, na mesma proporção, a necessidade de se apelar para a distribuição dos encargos do art. 333 do CPC. Na verdade, aumenta a probabilidade de um julgamento correto, conforme a vontade do legislador. As regras sobre o ônus da prova constituem a 'última saída para o juiz', que não pode deixar de decidir. São necessárias, mas devem ser tratadas como exceção, pois o que se pretende com a atividade jurisdicional é que os provimentos dela emanados retratem a realidade, não meras ficções". (BEDAQUE, José Roberto dos Santos. Poderes instrutórios..., cit., p. 124).

${ }^{25}$ SILVA, Homero Batista Mateus da. Op. cit., p. 223.
} 
não pode ser tomado como um ônus da referida parte. ${ }^{26}$

Refletir de modo diverso, além de conferir à parte um ônus que a lei não lhe atribui, é desarticular o ordenamento jurídico, uma vez que há, pelo artigo $7^{\circ}, \S 6^{\circ}$, da Lei $n^{\circ} 7.701 / 88$ (reprodutor do texto da Lei $n^{\circ} 4.725 / 65$ neste tocante), previsão de efeito suspensivo no recurso ordinário de dissídio coletivo, o que a jurisprudência alimenta, como praxe, apenas em relação a algumas cláusulas e não ao totum da norma. Ter-se-ia aí, caso contrário, a necessidade de se visualizar uma hipótese de modalidade de interrupção da prescrição apenas em relação às pretensões envolvidas nos direitos de tais cláusulas.

\subsection{A coisa julgada nas ações de cumprimento}

Ao se mencionar a expressão coisa julgada, deve-se ter em mente que não se trata de um instituto lido de uma maneira única. Contudo, apesar de suas variações, a coisa julgada é consubstanciada como elemento que confere proteção jurídica ao cidadão, pautando-se em imutabilidade do provimento e de seus efeitos.

Diante da perspectiva de suas várias dimensões, não se pode olvidar que, no caso das ações de cumprimento, a coisa julgada se apresenta com a dimensão rebus sic stantibus, bem como pode ter efeitos inter partes ou erga omnes.

Inexistem maiores problemáticas quanto aos efeitos inter partes ou erga omnes, vez que estes se moldam a partir da feição individual ou coletiva que assume, o que, por sua vez, se clareia conforme o legitimado ativo que a ela dá ensejo. Assim, em tendo a ação sido proposta, v.g, pelo MPT ou pelo sindicato profissional, o efeito da coisa julgada será erga omnes, restando a individualização à fase executiva do processo, e, no caso de um trabalhador ou alguns trabalhadores ingressarem com a mesma ação, esta terá feições individuais, sendo a coisa julgada analisada, também, de acordo com a feição individual que lhe é atinente.

A peculiaridade da coisa julgada na ação de cumprimento reside no fato de se dar como coisa julgada rebus sic stantibus. É que a coisa julgada da sentença na ação de cumprimento depende de condição resolutiva. Como se prescinde do trânsito em julgado para ingressar com mencionada ação, o estado de direito pode ser modificado na sentença normativa através de recurso ou através de ações anulatórias de cláusulas normativas. ${ }^{27}$

\footnotetext{
${ }^{26}$ No mesmo sentido, cf. SILVA, Homero Batista Mateus da. Op. cit., p. 223; e SANTOS, Ronaldo Lima dos. Sindicatos e ações coletivas..., cit., p. 334.

${ }^{27}$ Não se pode descurar ainda das hipóteses em que os ACT e CCT, que servem à consubstanciação da ação de cumprimento, e que a partir dela culmina em decisão transitada em julgado, venham a ter suas cláusulas desconstituídas a partir de conciliações efetivadas judicialmente mediante ACP, modificando a realidade jurídica
} 
Em sendo o pressuposto da ação de cumprimento a decisão normativa, passando esta a não mais existir, tem-se a perda da razão de ser daquela. Note-se que se privilegia, na ação de cumprimento proposta antes do trânsito em julgado da decisão normativa, a tempestividade da tutela jurisdicional (e a pronta vigência da norma oriunda do Poder Normativo) e, com a previsão da coisa julgada rebus sic stantibus, a visão da real instrumentalidade do processo.

O TST, através da Súmula $n^{\circ} 397$ e OJ n 277 da sua SDI I, comunga de idêntico espírito em relação ao processo.

Estêvão Mallet menciona que a faculdade de se ajuizar a ação de cumprimento antes do trânsito em julgado da decisão normativa implica no acatamento da existência de cláusula de revisão, uma vez que há condicionalismo passível de oscilação. Entretanto, perfilha de respeitável corrente contrária que prega que tal invocação somente pode ocorrer antes do manto da coisa julgada, sob pena de ofensa à CF neste tocante. ${ }^{28}$

Contudo, inserimo-nos na perfilhada corrente a esta antecedente, e, com Dinamarco, embora em outro prisma de relativização de coisa julgada, mas que serve também a este objeto, temos: "A coisa julgada não é em si mesma um efeito e não tem dimensão própria, mas dimensão dos efeitos substanciais da sentença sobre a qual incida, é natural que ela não se imponha quando os efeitos programados na sentença não tiverem condições de impor-se." 29

A coisa julgada da ação de cumprimento, pois, nesta ótica, configura demonstração cabal da instrumentalidade do processo, vez que apenas se perfaz imutável enquanto a situação jurídica da decisão normativa permanece inalterável, o que se justifica pela vigência de referida norma e pela possibilidade de alteração da decisão normativa pendente de recurso à época do trânsito em julgado da sentença desta decisão cognitiva que naquela se embasa.

\subsection{Os honorários advocatícios}

As distinções que assumem as ações de cumprimento, a partir do legitimado ativo, não se cingem a seu caráter individual ou coletivo, mas suplantam a todas as diferenciações que desta disparidade irradiam.

Assim como as ações individuais são regidas diretamente pela CLT e as propostas coletivamente regidas primacialmente pelo microssistema de tutela coletiva; assim como a

anterior. (SANTOS, Enoque Ribeiro dos. Efeitos do acordo judicial em sede de ação civil pública nas ações de cumprimento. Revista LTr, ano 74, p. 318-323, março de 2010).

${ }^{28}$ MALLET, Estevão. Prática do direito do trabalho. São Paulo: LTr, 2008, p. 173.

${ }^{29}$ DINAMARCO, Cândido Rangel. Nova era do processo civil. $3^{\text {a }}$ ed. São Paulo: Malheiros, 2009, p. 246. 
coisa julgada é analisada sobre prismas de efeitos diferenciados a partir do polo ativo, idêntica diversificação de tratamento deve se inserir na condenação em honorários advocatícios.

Embora tenham os Tribunais Trabalhistas ${ }^{30}$, por vezes, manifestado entendimento da impossibilidade de condenação em honorários advocatícios quando não houver benefícios de justiça gratuita, com base no disposto na Lei $n^{\circ} 5.584 / 70$, olvidava-se a verificação de que dita lei seria de aplicação direcionada à tutela individual, até porque é nessa que se faz constatável a impossibilidade de arcar com os custos do processo por algum indivíduo.

As ações coletivas, por sua própria natureza, implicam na despersonalização dos trabalhadores, sendo incoerência que, para fins de condenação dos honorários, tal identificação tivesse de ser feita. A aplicação deste entendimento de viés individual faz reaparecer a já expurgada exigência da lista de substituídos.

De outro lado, interpretações ampliativas de tal natureza levam ao entendimento desarrazoado de que a assistência deve ser mais priorizada que a própria substituição. Nesse contexto, as ações coletivas eram olvidadas, pois economicamente mais vantajosa se apresentar a assistência sindical, mediante ações individuais.

Constata-se, pois, que as ações de cumprimento devem encerrar aplicações diversas a partir da legitimação concretamente encetada. No caso de ação de cumprimento individual, não se discutiria a previsão da Lei $\mathrm{n}^{\circ} 5.584 / 70$, embora desarrazoadamente. Já quanto às ações de cumprimento de índole coletiva (direitos individuais homogêneos), o óbice à aplicação da lei reside no fato desta ter aplicabilidade consentânea à tutela dos direitos individuais com previsão clássica e se dissociar, completamente, dos ditames da tutela coletiva.

De uma forma geral, contudo, referida análise, a partir da Lei $n^{\circ} 13.467 / 2017$, com vigência a partir de 11.11.2017, deu novo fôlego a discussão ao modificar a previsão acerca dos honorários sucumbenciais nos processos trabalhistas em geral, aplicando-se inteiramente quer às ações de natureza individual ou coletiva, de modo que os honorários advocatícios sucumbenciais devem ser aplicados, inclusive de forma não compensatória.

\footnotetext{
${ }^{30}[. .$.$] HONORÁRIOS ADVOCATÍCIOS. SINDICATO. SUBSTITUTO PROCESSUAL. O ENTENDIMENTO$ DESTA CORTE, RESSALVADA A POSIÇÃO PESSOAL DA MINISTRA RELATORA, É NO SENTIDO DE QUE O SINDICATO, ATUANDO COMO SUBSTITUTO PROCESSUAL, FAZ JUS AOS HONORÁRIOS ADVOCATÍCIOS APENAS QUANDO PREENCHIDOS OS REQUISITOS EVOCADOS NA SÚMULA 219/TST. À FALTA DE UM DOS REQUISITOS, QUAL SEJA, A PROVA OU DECLARAÇÃO DE MISERABILIDADE JURÍDICA DOS SUBSTITUÍDOS, INDEVIDOS OS HONORÁRIOS ASSISTENCIAIS. RECURSO DE REVISTA INTEGRALMENTE NÃO CONHECIDO. (TST. RR - 83600-94.2006.5.03.0099. .3 $3^{\mathrm{a}}$ T. Rel. Min. Rosa Maria W. C. da Rosa. DEJT 16.04.2010).
} 


\section{CONSIDERAÇÕES FINAIS}

O tratamento dispensado à ação de cumprimento pelo art. 872 da CLT, hodiernamente, não é o suficiente para a leitura de mencionado instituto. O próprio âmbito de aplicação se encontra diferenciado da época de criação do instituto, eis que já há previsão não só para a tutela das normas anomalamente criadas pelo Poder Judiciário, mas também para a tutela das normas oriundas da negociação coletiva, com as convenções e acordos coletivos de trabalho.

Por outro lado, a própria chamada do direito processual para instrumentos mais consentâneos à realidade material, faz com que se pretenda uma adequada tutela procedimental.

Foi neste viés que se propôs e se desencadeou a tratativa da ação de cumprimento neste estudo, com um olhar mais atento às necessidades que o mundo material exige do direito processual.

Neste sentido, vislumbrou-se uma revisita a ação de cumprimento nos seus pontos fulcrais mais intricados, o que se observa: na coisa julgada, no tratamento conferido à prescrição, no procedimento aplicável insatisfatoriamente, o necessário alargamento do rol de legitimados ativos, a precisa remodelação das condenações em honorários advocatícios nas ações de cumprimento de índole coletiva, uma nova visão acerca da ausência de juntada do documento essencial (a exemplo da norma coletiva).

Não se descuidou também em analisar, nesse mesmo contexto de servir o direito processual ao direito material mais afetadamente, uma nova perspectiva sobre a iniciativa probatória do juiz, o que implica, sobretudo, nas ações de cumprimento manejadas por descumprimento de ACT e CCT, em uma necessária revisitação ao próprio momento de criação da norma, fato que pode vir a auxiliar num sistema sindical que tanto fragiliza a democracia como o do Brasil.

De outro lado, pontos mais genéricos foram abordados com o condão, não de repetição da literatura jurídica de outrora, mas de uma visão questionadora sobre o porquê do tratamento da ação de cumprimento da maneira como o foi, o que envolve questionamentos sobre a própria expressão e sobre a natureza jurídica.

Enfim, a realidade atual, imbricada pelo viés coletivo pede mudanças. E estas devem se operar processualmente a fim de refletir na vida material com soluções adequadas e efetivas. Foi, portanto, nesses termos que se propôs uma revisita às ações de cumprimento. 


\section{REFERÊNCIAS}

BEDAQUE, José Roberto dos Santos. Direito e processo - influência do direito material sobre o processo. $5^{\mathrm{a}}$ ed. São Paulo: Malheiros, 2009.

. Poderes instrutórios do juiz. $4^{\mathrm{a}}$ ed. São Paulo: Revista dos Tribunais, 2009.

DINAMARCO, Cândido Rangel. Nova era do processo civil. $3^{\text {a }}$ ed. São Paulo: Malheiros, 2009.

GIGLIO, Wagner D. Direito processual do trabalho. 13ª ed. São Paulo: Saraiva, 2003.

GONÇALVES, Emílio. Ação de cumprimento no direito brasileiro. $3^{\mathrm{a}}$ edição. São Paulo: LTr, 1997.

LEITE, Carlos Henrique Bezerra Leite. Curso de direito processual do trabalho. $6^{\text {a }}$ edição. São Paulo: LTr, 2008.

MALLET, Estêvão. Prática do direito do trabalho. São Paulo: LTr, 2008.

MARTINS FILHO, Ives Gandra. Processo coletivo do trabalho, $2^{\mathrm{a}}$ ed. São Paulo: LTr, 1996.

MELO, Raimundo Simão de. Processo coletivo do trabalho: dissídio coletivo, ação de cumprimento, ação anulatória. São Paulo: LTr, 2009.

Ação civil pública na justiça do trabalho. $3^{\mathrm{a}}$ ed. São Paulo: LTr, 2008.

NASCIMENTO, Amauri Mascaro. Compêndio de direito sindical. $2^{\mathrm{a}}$ ed. São Paulo: LTr, 2000.

RAMALHO, Maria do Rosário Palma. Da autonomia dogmática do direito do trabalho. Coimbra: Editora Almedina, 2000.

SAAD, Eduardo Gabriel. Consolidação das leis do trabalho: comentada. 39a ed. São Paulo: LTr, 2006.

SANTOS, Enoque Ribeiro dos. A negociação coletiva de trabalho como instrumento de pacificação social. In THOME, Candy Florêncio; SCHWARZ, Rodrigo Garcia (Org.). Direito coletivo do trabalho: curso de revisão e atualização. Rio de Janeiro: Elsevier, 2010.

Efeitos do acordo judicial em sede de ação civil pública nas ações de cumprimento.

Revista LTr, ano 74, p. 318-323, março de 2010.

SANTOS, Ronaldo Lima dos. Sindicatos e ações coletivas: acesso à justiça, jurisdição coletiva e tutela dos interesses difusos, coletivos e individuais homogêneos. $2^{\mathrm{a}}$ ed. São Paulo: LTr, 2008.

Teoria das normas coletivas. $2^{\mathrm{a}}$ ed. São Paulo: LTr, 2009. 
SILVA, Homero Batista Mateus. Curso de direito do trabalho aplicado, vol. 7: - direito coletivo do trabalho. Rio de Janeiro: Elsevier, 2010.

SÜSSEKIND, Arnaldo; MARANHÃO, Délio; VIANNA, Segadas; TEIXEIRA FILHO, João de Lima. Instituições de direito do trabalho, vol. 2. 19a ed. São Paulo: LTr, 2000.

TEIXEIRA FILHO, Manuel Antônio. Curso de processo do trabalho: perguntas e respostas sobre assuntos polêmicos em opúsculos específicos, n. 27: ação de cumprimento. São Paulo: LTr, 1998.

\title{
A NECESSARY REVISIT ACTION OF COMPLIANCE
}

\begin{abstract}
This article aims to approach the institute of compliance action, nomenclature girded by the legal literature for the institute created from article 872 of the Consolidation of Labor Laws. Intriguing questions, starting with the very design of the nomenclature, to go through the legal nature of the action involved and the identification of the legislator's choice in how to deal with it, culminating in specific specificities (about legitimacy and interests, applicable procedure , object and probative production, collation of essential documents, initial mark of prescription, res judicata and legal fees), deserve the dedication of its re-reading, in the perspective of collective law so celebrated (and rightly so) currently.
\end{abstract}

Keywords: Action. Fulfillment. Notions. Nature. Specificities. 